\title{
Remediation of Veliki bački kanal and sustainable use of resources in its surroundings
}

\author{
Vladimir StojanovićA, Milana PantelićA, Dragoslav PavićA, Imre NađB \\ Received: August 25, 2014 | Revised: October 29, 2014 | Accepted: November 14, 2014
}

\begin{abstract}
Veliki bački kanal is one of the most polluted watercourses in Serbia and it is frequently the central topic of the analysis of huge ecological issues in Serbia. It was dug at the turn of the $19^{\text {th }}$ century with the main purpose to drain the wetland areas in central Bačka and to enhance economic growth of the settlements that had been colonized several times during the 18th century. Although it is being studied mostly from environment protection perspective at present, it has been changing the features of the landscape and the environment in this area. The issue of intensive pollution, predominantly from food industry, has been increasing since the second half of the $20^{\text {th }}$ century. This type of pollution completely diminished the canal functions planned by the project designers. Current and future canal functions are: drainage and flood protection, irrigation, water supply, wastewater recipient, canal traffic, fish farming, tourism (recreation) and nature protection. Remediation is crucial and fundamental prerequisite for sustainable use or Veliki bački kanal resources.
\end{abstract}

Key words: Veliki bački kanal, pollution, remediation, sustainable development, landscape, resources

\section{Introduction}

The construction of Veliki bački kanal at the turn of the $19^{\text {th }}$ century was at that time one of the largest hydro-technical projects aimed at drainage of flooding areas and building inland navigable routes in Europe. In the beginning, the canal connected the Danube near Bački Monoštor and the Tisza near Bačko Gradište. Due to the relocation of the Danube waterbed during the mid $19^{\text {th }}$ century, the water intake structure was dislocated to the vicinity of Bezdan, whereas the mouth was dislocated to the vicinity of Bečej due to regulation works on the Tisza river (Milošev, 2002). Veliki bački kanal was integrated into the Hydro-system Danube-Tisza-Danube and divided into two canal sections in the second half of the $20^{\text {th }}$ century. The upstream section consists of canal Vrbas-Bezdan (80.9 $\mathrm{km}$ ), and the downstream section consists of the part of the canal Bečej-Bogojevo, between Bečej and triangle shaped area near Vrbas $(39.0 \mathrm{~km})$. Veliki bački ka- nal has four water gates and four ship locks: Bezdan, Mali Stapar, Vrbas and Bečej. The canal gets all its water gravitationally from the Danube and also by means of water intake pumps near Bezdan, then gravitationally over Bački kanal, by means of tributaries Krivaja and Beljanska bara and from the first aquifer (Likić, 2002; Pavić, et al., 2007; Public Utility "Vode Vojvodine").

Veliki bački kanal is probably the water course attracting most attention of the domestic general public regarding ecological and environment protection issues. There have been bombastic newspaper headlines in support of this statement: Veliki Bački Kanal Poisoned (daily newspaper Politika, July 21, 2007), Veliki Bački Kanal Europe's Black Spot (daily newspaper Blic, November 4, 2009), Veliki Bački Kanal Country's Stepson (daily newspaper Večernje novosti, May 18, 2013). In general, Veliki bački kanal is one of the most frequent ecological topics in Serbia and gener-

A Climatology and Hidrology Research Centre, Faculty of Science, University of Novi Sad, Trg Dositeja Obradovića 3, 21000 Novi Sad, Serbia

B Department of Geography, Tourism and Hotel Management, Faculty of Science, University of Novi Sad, Trg Dositeja Obradovića 3, 21000 Novi Sad, Serbia 
al public is familiar with its significance. Despite the numerous appeals, activities aimed at minimizing fatal environmental effects for this water course and the surrounding area have not commenced yet.

Significance of the topic pollution of Veliki bački canal may be observed from the point of view that rational and conscious water utilization is among the most important segments of environment protection. Theory and practice of sustainable development describe certain water issues as the ones of immense importance, such as: water scarcity, water use purpose, inefficient water use in towns, even and adjusted water distribution, and pollution (Elliott, 2013). Solution to the problem and water related issues are to be found in environment management (Barrow, 2006). Water protection issues impacted decision making processes for a series of important documents, which made water protection domain one of the most widely regulated in the European Union environmental legislation. Water Framework Directive (WDF) from 2000, regulating water policy frameworks, adheres to sustainable development and integral water management principles (Pantelić, 2012). Within the EU accession process, Serbia would need to intensify discussion on these issues and such trend should not be observed only as fulfilling prescribed standards, but understood as essential process in environment and resources protection.
Wastewater release into surface water courses has reached and alarming level and become one of the serious problems (Alvarez-Vázquez, et al., 2009). This trend is the main problem of Veliki bački kanal and one of the reasons why this water course resources remain unused for local community welfare.

\section{History of digging the canal and its impact on landscape features in central Bačka}

The canal digging occurred due to historical circumstances in this region during the 18 th century coupled with natural features of the surroundings and wider area of the Pannonian plain. At the end of the $17^{\text {th }}$ century and the beginning of the $18^{\text {th }}$ century, southern parts of the Pannonian plain (present Vojvodina) were so sparsely populated that the areas were leaving the impression of deserts and the areas were mapped as such. This was particularly true for inner parts of Bačka (Popović, 1990). In 1699, Bačka became a part of Austria (Treaty of Karlovci) instead of Turkey. The area changed drastically from new spatial organization and new economic ideas to colonisations which had to revitalize it demographically (Lazić, et al., 1998). Due to the total negligence of water courses during the Turkish reign there were frequent floods and huge wetlands were formed

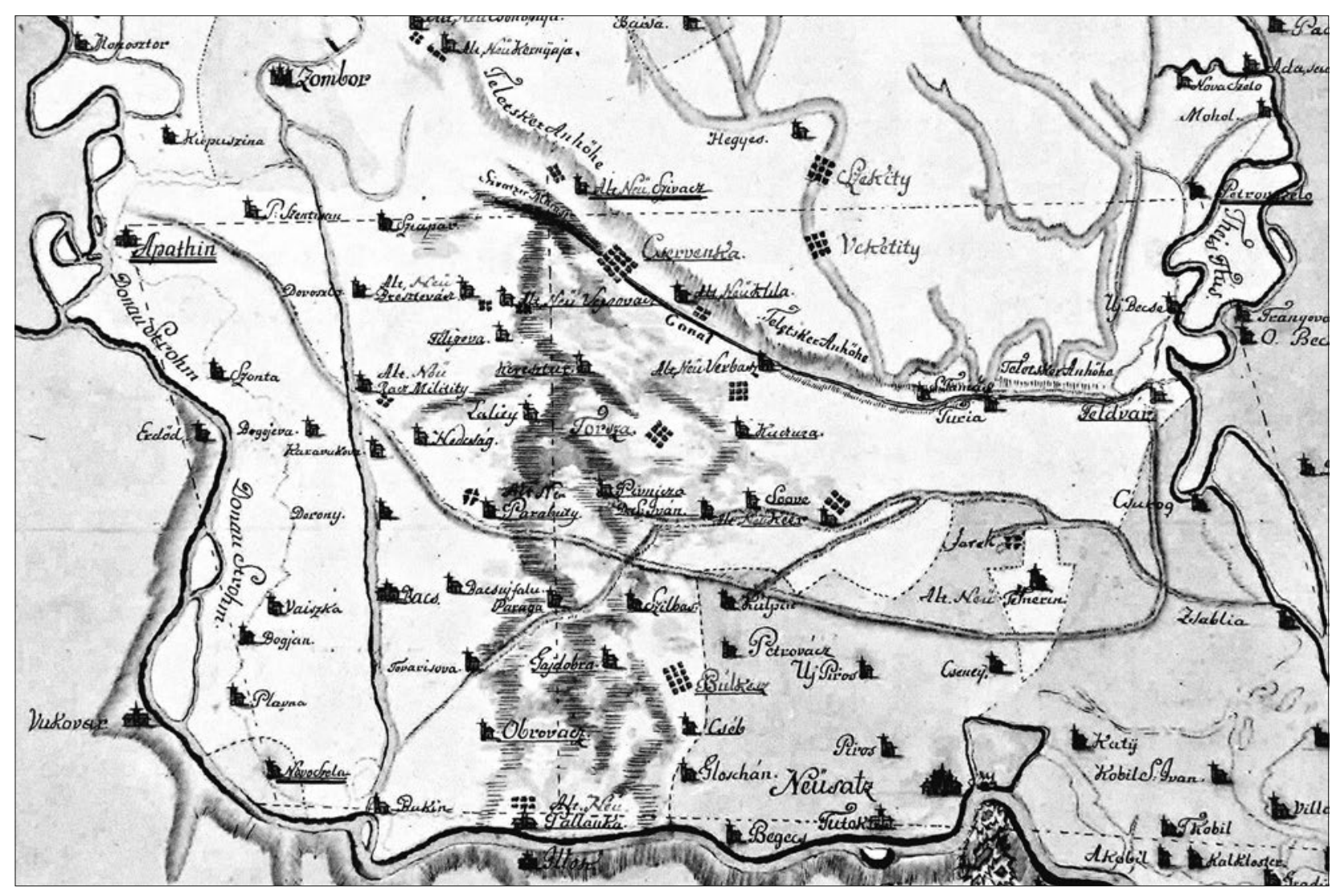

Figure 1. Map of central and southern Bačka from 1787 with flooded settlements due to the groundwater level rise. Source: National Archives of Hungary, Budapest 
(Popović, 1996). Such situation was unfavourable for the new settlers and new economic projects - primarily the idea of turning this area into cultivated land; therefore certain interventions in the environment were inevitable.

Ethnically dominant among the settlers were Germans who colonized this area on several occasions during the $18^{\text {th }}$ century and remained dominant by the end of the World War II (Kicošev, et al., 2006). Wetlands threatened to spoil the success of the colonization in the $18^{\text {th }}$ century. Huge mud areas and wetlands were spreading around Sivac, on the bank of the present Veliki bački kanal; numerous bogs covered in reed were stretching from the time immemorial along the southern rim of Telečka visoravan, which is today the course of the canal (Petrović, 1978). Crna bara was stretching east from Vrbas and causing numerous problems (Pantelić, 2012).

The solutions to the accumulated problems in this part of Bačka were searched for in the project of Veliki bački kanal designed by brothers József and Gabor Kiss. The construction of the canal lasted from 1793 to 1802. The first function of the canal was draining the wet soil in central Bačka and shortening the navigable route between the Danube and the Tisza for approximately $160 \mathrm{~km}$ (Milošev, Stojanov, 1998). The project was successful with respect to the first task, since in the initial construction phase between Sivac and Kula, water withdrawal was recorded for the areas previously covered in water. József Kiss, encouraged with such success, dug a wider and longer canal $(30 \mathrm{~km})$ between Sivac and Vrbas with the permission of Hungarian chamber for the purposes of draining the excess water from the depression of Sivac into Crna bara (Petrović, 1978). Comparison of archive maps from the period prior to the canal construction give evidence about complete transformation of landscape features of the canal course. The rising level of Sivačka bara would cause flooding of the nearby settlement Veprovac (today Kruščić), and floods would spread towards south up to Odžaci prior to the canal construction (Figure 1). After the construction of the canal, embankments and roads, the area obtained completely different features in a short period (Figure 2).

\section{Pollution of Veliki bački kanal}

Pollution of Veliki bački kanal reached its peak in the second half of the $19^{\text {th }}$ century, although the problem had appeared a bit earlier. A fish kill that occurred in 1936 in the canal near Srbobran was caused by water pollution from Vrbas sugar factory (Pantelić, 2012). The apprehension of Veliki bački kanal pollution may be obtained from the pollutant cadastre (Official Gazette of the Republic of Serbia No. 135/04), which is

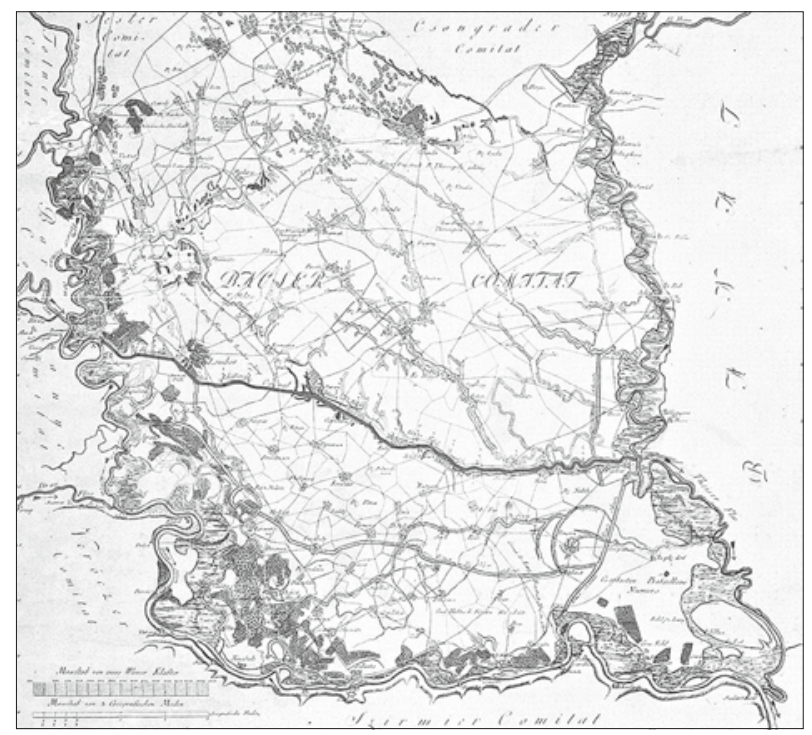

Figure 2. Map of Bačka from the $19^{\text {th }}$ century, after the digging of Veliki bački kanal. Wetlands are found only on the banks of the Danube and the Tisza

the prerequisite for regular data collection, analysis, synthesis, presentation to interested legal and natural persons (Dalmacija, 2004).

There are 24 industrial objects within the group of pollutants of Veliki bački kanal (Table 1). Most of them are food industry plants. This industrial branch is a huge water consumer and its process water has high levels of organic matter. Data on mean values of wastewater quality for all concentrated water on the course of Veliki bački kanal indicate that wastewater from meat and meat processing industry pose the greatest hazard due to high concentration and quantity of organic pollutants. Another threat comes from utility services in Kula and Vrbas. Moreover, huge problem is sedimentation of suspended solids (that fill the canal with sediment), microorganisms use oxygen for these compounds oxidation processes, and also the release of nutrients (phosphorus and nitrogen), that stimulate the growth of water plants (Pantelić, 2012). Detailed research shows that industrial wastewater is far more burdened with organic elements than standard municipal wastewater. It has been confirmed that waste from industrial wastewater is less biodegradable than that from standard municipal wastewater (Krčmar, 2006).

Besides the water quality problems, special issue is a huge amount of mud, an estimate of approximately $400.000 \mathrm{~m} 3$, at the most endangered section of Veliki backki kanal in the total length of six river kilometres near Vrbas. Such large quantity of mud caused the canal to become unnavigable due to its depth of only $30 \mathrm{~cm}$ at certain points. In general, the sediment of Veliki bački kanal is a problem based on pseudo total metal content because the classification of studied profiles indicate that the value of at least one met- 
Table 1. List of concentrated pollutants on the Veliki bački kanal route

\begin{tabular}{|c|c|}
\hline № & Pollutants \\
\hline 1. & JKP "Vodovod" Sombor \\
\hline 2. & "Panonka" Sombor \\
\hline 3. & "Sunce" Sombor \\
\hline 4. & "Crvenka" AD \\
\hline 5. & DOO "Panon 021" Crvenka \\
\hline 6. & "Jaffa" Crvenka \\
\hline 7. & JKP "Vodovod" Crvenka \\
\hline 8. & AD "Eterna" Kula \\
\hline 9. & JKP "Komunalac" Kula \\
\hline 10. & DOO "Stork" Kula \\
\hline 11. & AD "Carnex" Vrbas \\
\hline 12. & AD "Carnex" PJ "Farmacoop" Vrbas \\
\hline 13. & JKP "Standard" OJ "Vodovod i kanalizacija" Vrbas \\
\hline 14. & AD "Bačka" Vrbas \\
\hline 15. & AD "Vital" Vrbas \\
\hline 16. & AD "Medela" Vrbas \\
\hline 17. & DD "Trivik-Pek" Vrbas \\
\hline 18. & "Reahem" DOO RJ "Elan" Srbobran \\
\hline 19. & JKP "Graditelj" Srbobran \\
\hline 20. & AD "Bag" Bačko Gradište \\
\hline 21. & PIK "Bečej" RJ "Flora" Bečej \\
\hline 22. & DOO HKC "Fadip" Bečej \\
\hline 23. & JKP "Vodokanal" Bečej \\
\hline 24. & DD "Remont" Bečej \\
\hline
\end{tabular}

Source: Internal documents PU "Vode Vojvodine", 2010.

al may have negative effects on water ecosystem with regard to classification of studied profiles (Krčmar, 2010).

\section{Remediation of Veliki bački kanal}

Remediation is a process of introducing measures for cutting pollution and further degradation of the environment up to the level at which future use of the locality including spatial planning, revitalization and recultivation is safe (Krčmar, 2010). The pollution of Veliki bački kanal and health hazard for the inhabitants of this region has been continuous for eighty years. However, harmful consequences spread further to the Tisza and the Danube river and become international. The application of appropriate technological procedures for wastewater sanitation would reduce the excess organic pollution loading imposed on this body of water, i.e. Veliki bački kanal. Sanitation also implies mud removal and its safe disposal, revitalization of certain objects, restructuring works on the canal banks, fish introduction, and bringing the canal into the condition when sustainable development principle is achieved by means of routine maintenance. Industrial wastewater may be treated by application of joint treatment with municipal wastewater or separately (Wang, et al., 2005; Hongxia, et al., 2004). Moreover, application of various methods such as wastewater treatment by means of membrane filtration process to remove active mud may have high efficiency of removing organic, nitrogen and phosporous elements from wastewater (Krčmar, 2006).

One of the leading environmental issues in the surroundings of Veliki backi kanal is the impact of food industry wastewater. The treatment of this wastewater is similar to treatment of municipal wastewater. In practice, all usual techniques applied in municipal wastewater treatment are also applied in food industry wastewater treatment (Dalmacija, et al., 2011). However, there is one difference that should be highlighted: anaerobic wastewater treatment techniques are used more frequently in wastewater treatement compared to municipal wastewater treatment. Anaerobic wastewater treatment techniques are suitable for highly contaminated wastewater and frequently combined with aerobic treatment, first anaerobic treatement is applied and then follows aerobic treatement. Application of anaerobic and aerobic treatments instead of only aerobic treatment may reduce costs of wastewater treatment works and also for factor eight (Chan, et al., 2009). On the other hand, there is a surprising finding obtained from the comparison of the emission of greenhouse gases (expressed in euqivalent quantity of carbon dioxide) during three types of processes in food industry wastewater treatment: aerobic (aerobic mud removal and use of biogas), anaerobic and combined anaerobic-aerobic process. Conversely, the most efficient one with regard to greenhouse gases emission is aerobic system with anaerobic mud removal, but not combined anaerobic-aerobic process as might have been expected (Shahabadi, 2009). Food industry in Serbia applies anaerobic wastewater treatment sporadically, but there has been evidence of growing interest in anaerobic wastewater treatment lately.

In order to reduce pollution of Veliki bački kanal, first, all pollutants should cease untreated wastewater release. Next, the sanitation and revitalization of the canal may start (mud removal and cleaning, mud depositing, sanitation of other objects, aquatic vegetation removal, fish introduction and other works aimed at canal revitalization). Also, it is necessary to monitor, maintain and utilize the canal according to the principles of sustainable development. Detailed analyses and recordings indicate that sanitation and revitalization of the canal is pointless unless the caus- 
es of the current condition are eliminated and the consequences diminished for a longer period (Action plan, 2005). The first and foremost solution for pollution reduction is the construction of municipal wastewater collecting, conveyance and treatment facilities with the aim of canal water quality maintenance pursuant to legal regulations. Numerous studies and analyses have shown that the problem of wastewater treatment may be solved optimally by means of constructing joint central facilities for wastewater treatment (CPPOV).

Currently, municipal and industrial wastewater is released into Veliki bački kanal either untreated or inadequately treated thus endangering the quality of its water. The analyses of canal water and sediment quality point out to the completely degraded water quality and sediments in the canal, which may become human health hazard, endanger the canal function and quality of the environment of the borader region.

\section{Functions and sustainable development of Veliki bački kanal resources}

Analysis of usefulness i.e. functions of Veliki bački kanal was performed back in 1791 by its project designers, the Kiss brothers (Figure 3), because Austrian economic administration was primarily interested into it. First, the canal navigability significance was highlighted. The construction of the canal shortened the navigable route from Szeged, the main salt port for the eastern part of the monarchy, to the Danube. In the vicinity of the canal's contact with the Tisza river there is the canal's mouth into the Begej river, which is the shortest link to the mines of the Carpathians. At that time the trade in Bačka declined and the canal would provide the perspective for its revitalization (Petrović, 1978). The industry also benefited from the canal, which is observable in the fact that several settlements on the bank of the canal had the role of important role of local and regional industrial centres in the $19^{\text {th }}$ and $20^{\text {th }}$ century, among which were: Sombor, Crvenka, Kula, Vrbas, Srbobran and Bečej. Food industry was the main industrial branch, especially bread making, meat processing, sugar, confectionery and vegetable fat and oil industry. This industrial region was one among three largest in Bačka, together with Podunavlje and Potisje (Tomić, et al., 2005). Finally, although not mentioned among the first benefits, the benefit of meliorations is undisputable, since they changed the features of the landscape, but provide progress for agricultural production. It is especially remarkable east from Vrbas, where Crna bara as an elemental and uncontrolled aquatoria finally obtained a multifunctional course.

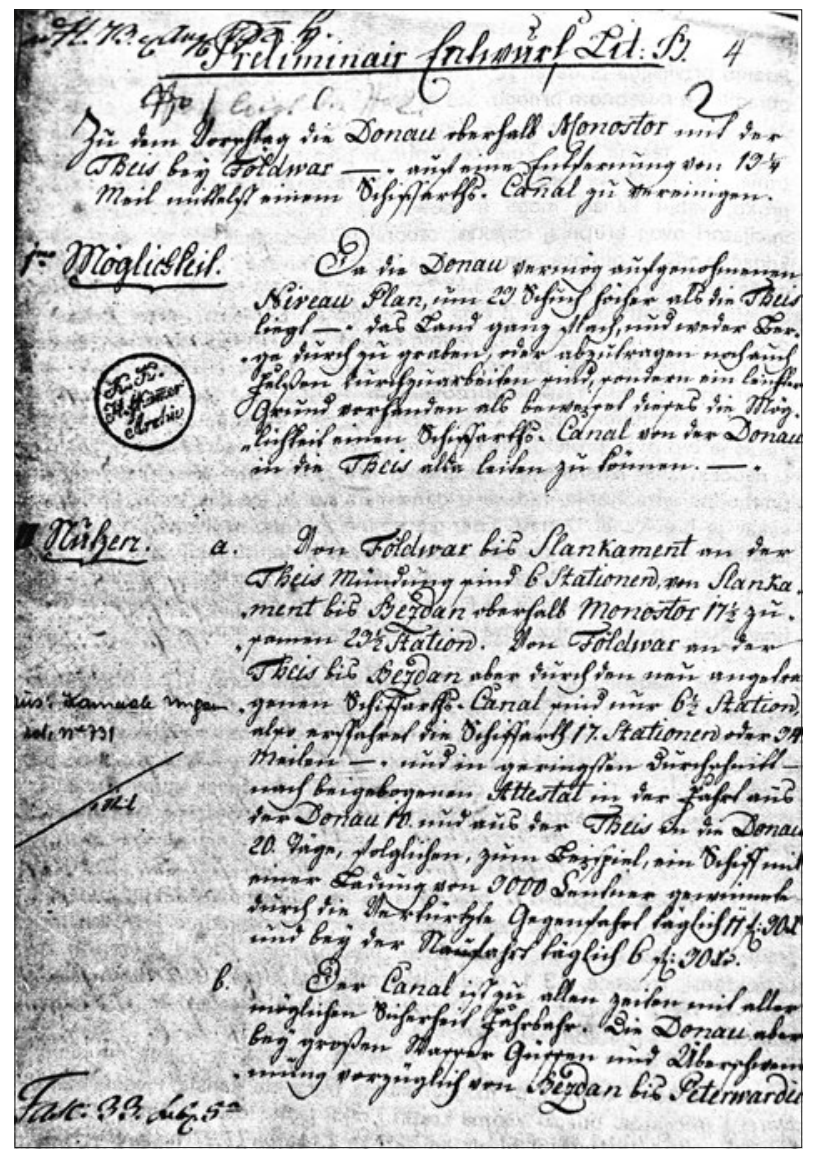

Figure 3. József and Gabor Kiss's proposal on possibilities of Veliki bački kanal development

After the World War II, Veliki bački kanal was included into Hydro-system Danube-Tisza-Danube. The idea on its building was in concordance with the concept of comprehensive water problems solution and general discussions on the idea in the period 1945-1947 (Milovanov, 1972). This was one of magnificent and immensely important projects in former Yugoslavia. Parallel to its planning and construction, the possibilities of its use and functions of canal network were discussed. The base of the whole idea was a unique hydromelioration system with multiple agricultural purposes such as: navigation, water supply for industry and settlements, fish farming with fish ponds in canal network, recreation and tourism (Subotički, 1972). Current and future use of Veliki bački kanal potentials is linked to the idea of sustainable development (Pantelić, 2012). Basic functions of the canal with regard to this issue are: drainage, irrigation, water supply, wastewater recipient, canal traffic, fish farming, tourism (recreation) and nature protection. There are ten settlements on the bank of the canal with the population of 130,000. The aforementioned functions are of vital importance for their lives and work. Urban and ecological problems would be solved by sanitation of those problems and the towns would become better places for living (Vrbas, Kula, Crvenka and Srbobran). 
Table 2. Current functions of Veliki bački kanal and sustainable development projection

\begin{tabular}{|c|c|c|}
\hline Function & Current situation & Sustainable development projection \\
\hline Drainage & $\begin{array}{l}\text { Drainage is the sector in which the planned effects } \\
\text { were mainly reached after the digging activities. } \\
\text { Today, this function is satisfactory. }\end{array}$ & $\begin{array}{l}\text { Apply more intensive maintenance of the } \\
\text { drainage system and canal network with a } \\
\text { number of objects, since the present one is as } \\
\text { low as 35\% of the real needs. }\end{array}$ \\
\hline Irrigation & $\begin{array}{l}\text { First, irrigation has an immense role in agricultural } \\
\text { development. As a part of Hydro system DTD, the } \\
\text { canal does not meet the needs of this function with } \\
\text { regard to the scope, technical equipment and water } \\
\text { quality. }\end{array}$ & $\begin{array}{l}\text { Sustainable irrigation is the base for high quality } \\
\text { agriculture and it provides regional economic } \\
\text { safety. }\end{array}$ \\
\hline Water supply & $\begin{array}{l}\text { Use of water for industrial processes under } \\
\text { conditions when water supply systems remain } \\
\text { unprotected. }\end{array}$ & $\begin{array}{l}\text { Improving water quality to the optimum level in } \\
\text { order to use it primarily in food industry. }\end{array}$ \\
\hline $\begin{array}{l}\text { Wastewater } \\
\text { recipient }\end{array}$ & $\begin{array}{l}\text { According to the main idea, the canal is a } \\
\text { multipurpose object functioning as a recipient of } \\
\text { treated wastewater. Annually, the canal receives } \\
\text { several million m3 of wastewater. Present condition } \\
\text { of this function is totally unsustainable. }\end{array}$ & $\begin{array}{l}\text { Increase wastewater treatment. The canal needs } \\
\text { to become recipient only for treated wastewater, } \\
\text { decontaminated of substances harmful for } \\
\text { ecosystem. }\end{array}$ \\
\hline Canal traffic & $\begin{array}{l}\text { This sector failed to achieve results specified in } \\
\text { the canal digging project. The obstacles for its } \\
\text { navigability are low-rise bridges and large quantities } \\
\text { of silt (in Vrbas } 350,000 \mathrm{~m} 3 \text {, depth } 30-40 \mathrm{~cm} \text { ). }\end{array}$ & $\begin{array}{l}\text { Overcome the difficulties in canal traffic: silt } \\
\text { removal, water pollution prevention, waterfront } \\
\text { spatial planning, canal traffic marketing, and } \\
\text { nautical service providers. }\end{array}$ \\
\hline Fish farming & $\begin{array}{l}\text { Due to small water flow and slight oscillations } \\
\text { of water level, the conditions are favourable for } \\
\text { breeding various fish species (carp, pike, catfish, } \\
\text { pike perch, sturgeon). Polluted water is a limiting } \\
\text { factor for fish farming in certain areas. Extremely } \\
\text { destructive pollution occurs in September and } \\
\text { October (sugar industry wastewater). }\end{array}$ & $\begin{array}{l}\text { Sustainable utilization of this potential must } \\
\text { include: controlled fishing, introduced fish } \\
\text { population, adapted water regime. It is necessary } \\
\text { to abide by the decision on commercial fishing } \\
\text { prohibition and promote sports fishing. }\end{array}$ \\
\hline Tourism (recreation) & $\begin{array}{l}\text { Pollution level in most parts of the canal prevents } \\
\text { its use for tourism and recreation purposes. } \\
\text { Recreational zones are mainly situated in the part } \\
\text { of the canal near the town of Sombor. Monuments } \\
\text { of technical culture (ship locks, pumping stations, } \\
\text { mills) cannot be included into presentation. }\end{array}$ & $\begin{array}{l}\text { Each tourism development plan depends } \\
\text { exclusively on successful remediation measures. } \\
\text { Cultural landscape values and cultural heritage } \\
\text { should be included into such plans. Recognisability } \\
\text { and cultural branding of the canal should be } \\
\text { insisted on (cultural heritage objects: Mali Stapar, } \\
\text { ship lock near Bezdan, ship lock near Bečej, etc.). }\end{array}$ \\
\hline
\end{tabular}

\section{Conclusion}

Despite its significant historical role in shaping the landscape and contributing to economic growth of central Bačka, Veliki bački kanal has been experiencing the largest problems with regard to environment protection in Serbia due to negligence. Similarly to other hydrological objects of anthropogenic origin, the issue of the canal usefulness stands as crucial segment in overall valorisation of not only the water course, but also its immediate surroundings. The canal functions and their realisation have been burning issues for numerous nearby settlements ever since the 18 th century, i.e. the time when the canal was dug and up to the most recent studies on its sanitation and remediation. Almost all current plans and studies on environment protection mainly rely on pollution indicators and remediation possibilities. However, none of the studies highlights its historical significance or analyses it as an important segment within cultural landscape in this part of the country. According to the fact that sustainable development rests on three fundamental principles - ecological, economic and social-cultural, introduction of a wider social and cultural criterion into overall valorisation would facilitate the canal reconstruction plans.

\section{Acknowledgment}

The authors acknowledge the financial support of the Ministry of Education and Science of the Republic of Serbia (Project III 43005).

\section{References}

Action plan for pollution reduction of the canal sections HS DTD Vrbas-Bezdan and Bečej-Bogojevo, 2005, Novi Sad. (In Serbian) 
Alvarez-Vázquez, Martinez, A., Vázquez-Mendez, M. E., Vilar, M. A. 2009. An application of optimal control theory to river pollution remediation. Applied Numerical Mathematics 59, 845-858.

Barrow, C. 2006. Environmental Management for Sustainable Development, Routledge, London and New York.

Chan Y.J., Chong M.F., Law C.L., Hassell D.G. 2009. A review on anaerobic-aerobic treatment of industrial and municipal wastewater. Chemical Engineering Journal 155, 1-18.

Dalmacija, B. 2004. Analysis and innovation of information subsystem of used water, Department of Chemistry, Faculty of Sciences. Novi Sad. (In Serbian)

Dalmacija B., Bečelić-Tomin M., Klašnja M., Dalmacija M., Rončević S., Krčmar D., Agbaba J., Tričković J., Karlović E., Pešić V. 2011. Granične vrednosti emisije za vode. University of Novi Sad, Faculty of Sciences. Department of Chemistry, Biochemistry and Environment Protection, Novi Sad. (In Serbian)

Data base of Public Utility Vode Vojvodine. (In Serbian)

Daily newspaper Politika, Veliki Bački Kanal Poisoned, July 21, 2007. (In Serbian)

Daily newspaper Blic, Veliki Bački kanal Black Spot of Europe, November 4, 2009. (In Serbian)

Daily newspaper Večernje novosti, Veliki Bački Kanal Country's Stepson, May 18, 2013. (In Serbian)

Elliott, J. 2013. An Introduction to Sustainable Development, Routledge, London and New York.

Hongxia, Y., Jing, C, Yuxia, C, Huihua, S., Zhonghai, D., Hongjun, J. 2004. Application of toxicity identification evaluation procedures on wastewaters and sludge from a municipal sewage treatment works with industrial inputs. Ecotoxicology and Environmental Safety 57 (3), 426-430.

Internal archives JVP Vode Vojvodine 2010. (In Serbian)

Kicošev, S., Bubalo-Živković, M., Ivkov, A. 2006. Population of Bačka. Geographical aspects of condition and development directions of Serbia. Department of Geography, Tourism and Hotel Management. Faculty of Sciences. Novi Sad. (In Serbian)Knežević L., Petrović G., (200o): Glossary - Environment protection, ecology and i environology. Recycling Agency, Republic of Serbia. (In Serbian)

Krčmar, D. 2006. Research of Vrbas-Kula-Crvenka industrial basin wastewater impact on Veliki bački kanal, Master thesis, Department of Chemistry, Faculty of Sciences. Novi Sad. (In Serbian)

Lazić, L., Bubalo, M., Pavić, D. 1998. Population of the Mostonga catchment area and west Bačka. The Mostonga and water courses in west Bačka. Edition “Tija voda”. PČESA. Novi Sad, 161-178. (In Serbian)
Likić, B. 2002. General review of Hydro-system Danube-Tisza-Danube. Hydro-system Danube-TiszaDanube - 25 years after, Public Utility "Vode Vojvodine", Novi Sad, 41-58. (In Serbian)

Milovanov, D. 1972. Concept development and hydrosystem Danube-Tisza-Danube realization. Hydrosystem Danube-Tisza-Danube. Public Utility Danube-Tisza-Danube. Novi Sad. (In Serbian)

Milošev, Ž., Stojanov, V. 1998. Flood protection, The Mostonga and water courses of west Bačka. Edition “Tija voda”. PČESA. Novi Sad. (In Serbian)

Milošev, Ž. 2002. Hydro-technical works in Banat and Bačka prior to Hydro-system Danube-Tisza-Danube construction, Hydro-system Danube-TiszaDanube - 25 years after, Public Utility "Vode Vojvodine", Novi Sad, 1-21. (In Serbian)

National Archives of Hungary, Budapest. (In Serbian) Official Gazette of the Republic of Serbia, No. 135/04 (In Serbian)

Pantelić, M. 2012. Sanitation and protection of Veliki bački kanal as the prerequisite of sustainable use of its development potentials. Doctoral thesis-unpublished. Department of Geography, Tourism and Hotel Management. Faculty of Sciences. Novi Sad. (In Serbian)

Pavić, D., Stojanović, V., Mesaroš, M. 2007. Significance of Hydro-system Danube-Tisza-Danube canal network for nautical tourism in Vojvodina. Scientific Journal Turizam No. 11: 37-41. (In Serbian)

Petrović, N. 1978. Navigation and economy of Middle Danube Basin during Merkantilism, Historical Institute, Belgrade. (In Serbian)

Popović, D. 1990. Serbs in Vojvodina, Vol. 2, From Treaty of Karlovci in 1699 to Timisoara Assembly in 1790, Matica srpska, Novi Sad. (In Serbian)

Popović, V. 1996. Water management development in Novi Bečej for the period 1845-1995, Novi Sad. (In Serbian)

Shahabadi, M.B., Yerushalmi, L., Haghighat, F. 2009. Impact of process design on greenhouse gas (GHG) generation by wastewater treatment plants. Water Research 43, 2679-2687.

Subotički, S. 1972. Economic significance of Hydrosystem DTD. Hydro-system Danube-Tisza-Danube. Water management company Danube-TiszaDanube. Novi Sad. (In Serbian)

Tomić, P., Romelić, J., Jovanović, G. 2005. Industry of Bačka. Geographical aspects of condition and development perspectives of Serbia. Department of Geography, Tourism and Hotel Management. Faculty of Sciences. Novi Sad. (In Serbian)

Wang, C, Hu, X., Chen, M.L., Wu, Y.H. 2005. Total concentrations and fractions of $\mathrm{Cd}, \mathrm{Cr}, \mathrm{Pb}, \mathrm{Cu}, \mathrm{Ni}$ and $\mathrm{Zn}$ in sewage sludge from municipal and industrial wastewater treatment plants. Journal of Hazardous Materials 119, 245-249. 